\title{
Pengolahan Potensi Tanaman Jagung dan Peningkatan Produksi Pertanian Melalui Metode Hidroponik di Desa Jurangjero
}

\author{
Fransiska Olivia ${ }^{1}$, Nadia Rhema ${ }^{2}$, Krisna Wijayanto ${ }^{3}$, Yudha Pande Raja ${ }^{4}$, Kevin ${ }^{5}$, Muhammad Evan Varian ${ }^{6}$, Hewitt Kheng ${ }^{7}$, \\ Marselinus Bagas Krisnayuda ${ }^{8}$, Agung Tri Atmadi ${ }^{9}$, Daniel Tri Dharmawan Santoso ${ }^{10}$, Ika Murti Kristiyani ${ }^{11}$ \\ Universitas Atma Jaya Yogyakarta, Jl. Babarsari No.44, Janti, Caturtunggal, Kec. Depok, Kabupaten Sleman, Daerah Istimewa Yogyakarta \\ 55281 \\ Email : ika.murti@uajy.ac.id
}

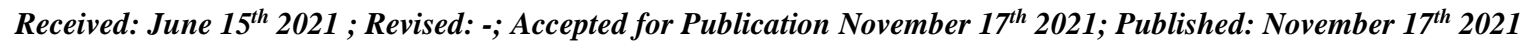

\begin{abstract}
This research focuses on processing village potential products and increasing agricultural production through hydroponic methods. The main livelihood of the Jurangjero villagers is mostly agriculture or plantations. This research was conducted to help villagers who have the potential for their agricultural or plantation products. The villagers can change how they cultivate plants to make them more effective, especially in terms of land use and maintenance. The limitations of knowledge and technology that support the sustainability of the agricultural system are the factors that make villagers still apply a relatively simple agricultural system. This study aims to provide empowerment and knowledge to villagers and general society to better know how to utilize the potential of the existing village and implement a more effective agricultural system. The method in this study uses a qualitative descriptive method, where researchers tend to emphasize more on analysis descriptively from the data obtained. The results expected from this research are in the form of processing village potential, namely corn plants into corn milk products, and utilize hydroponic methods to support the cultivation of agricultural or plantation crops. This program becomes an innovation that is applied to assist in developing agricultural systems and increase community yields.
\end{abstract}

Keywords - Village potential, Hydroponics, Corn plants, Agriculture

Abstrak - Penelitian ini difokuskan pada pengolahan hasil potensi desa dan peningkatan produksi pertanian melalui metode hidroponik. Mata pencaharian utama warga Desa Jurangjero sebagian besar adalah pertanian atau perkebunan. Penelitian ini dilakukan untuk membantu warga desa yang memiliki potensi hasil pertanian atau perkebunan. Warga desa bisa mengubah cara mereka membudidayakan tanaman agar lebih efektif, terutama dalam penggunaan lahan serta perawatannya. Keterbatasan akan pengetahuan dan teknologi yang menunjang keberlangsungan sistem pertanian adalah faktor yang membuat warga desa masih menerapkan sistem pertanian yang terbilang sederhana. Tujuan penelitian ini untuk memberikan pemberdayaan dan pengetahuan kepada warga desa dan masyarakat secara umum untuk lebih mengetahui cara memanfaatkan potensi desa yang ada dan menerapkan sistem pertanian yang lebih efektif. Metode dalam penelitian ini menggunakan metode deskriptif kualitatif, dimana peneliti lebih cenderung menekankan pada analisis secara deskriptif dari data yang diperoleh. Hasil yang diharapkan dari penelitian ini berupa pengolahan potensi desa yaitu tanaman jagung menjadi produk susu jagung, dan pemanfaatan metode hidroponik untuk menunjang cara dalam budidaya tanaman pertanian atau perkebunan. Program ini menjadi inovasi yang dapat diterapkan untuk membantu pengembangkan sistem pertanian dan peningkatan hasil panen warga.
Kata Kunci - Potensi desa, Hidroponik, Tanaman jagung, Pertanian

\section{PENDAHULUAN}

Penelitian ini adalah salah satu bentuk pengabdian kepada warga Desa Jurangjero, Ngawen, Gunung Kidul, Yogyakarta. Desa ini memiliki potensi hasil perkebunan berupa tanaman jagung. Dalam angka Kecamatan Ngawen, luas lahan panen jagung pada tahun 2019 sebesar $1079 \mathrm{Ha}$, kemudian pada tahun 2020 mengalami peningkatan sebesar 1327,1 Ha. Pengabdian yang dilakukan ini berupa pengolahan potensi tanaman jagung menjadi produk susu jagung, dan peningkatan produksi pertanian melalui metode hidroponik. Program yang dilakukan bagi warga desa ini membantu dalam pembuatan produk olahan susu jagung karena jagung merupakan sumber utama yang ada di desa tersebut, sedangkan metode hidroponik diterapkan agar tingkat penggunaan lahan pertanian/perkebunan warga desa tidak menggunakan lahan terlalu besar. Dengan metode hidroponik, tanaman akan tetap bisa tumbuh subur, ketika unsur hara dapat terpenuhi secara seimbang. Hidroponik juga memiliki keuntungan tersendiri terutama bagi lingkungan sosial, karena dapat dijadikan sarana pendidikan dan pelatihan pelatihan pada bidang pertanian modern [1].

Jagung merupakan salah satu alternatif bahan pangan pokok selain beras, namun sneks ragam jenis olahan jagung sebagai bahan baku atau makanan/minuman lainya kurang diminati oleh masyarakat. Jika dilihat dari kandungan gizinya, jagung kaya akan karbohidrat, vitamin, serat, dan mineral lainnya. Jagung mengandung serat pangan yang tinggi, kadungan gizi utama jagung adalah pati. Kandungan pati pada jagung lebih tinggi dari pada protein, sehingga jagung bukan menjadi sumber protein yang utama [2]. Dengan demikian seharusnya jagung mempunyai potensi sebagai bahan pangan dan bahan baku industri yang akan memberikan nilai tambah bagi para petani jagung.

Dalam rangka upaya memenuhi kebutuhan pangan yang terus meningkat, maka petani diharapkan bisa meningkatkan produktivitas pertanian. Pengabdian ini dilakukan agar sumber daya atau potensi yang ada di desa menjadi bermakna dan mempunyai manfaat bagi kehidupan. Warga desa memperoleh pembelajaran mengenai bagaimana cara mengolah hasil pertanian dan menerapkan metode yang lebih berbeda. Pengembangan jagung melalui diversifikasi konsumsi di masa mendatang memungkinkan masyarakat mengkonsumsi jagung dalam jumlah banyak. Pengembangan produk olahan jagung dapat meliputi cita rasa dengan 
tampilan menarik dan aman untuk dikonsumsi. Penyajian dan pengemasan produk olahan jagung yang menarik dan aman dapat mempermudah untuk dibawa sehingga bisa dikonsumsi kapan saja dan dimana saja.

Selain potensi jagung, masyarakat Desa Jurangjero masih banyak yang menjadi petani sehingga mereka menggunakan "adat setempat" yaitu sistem tonjo dalam pertanian. Sistem tonjo dilakukan dengan cara petani membuat lubang satu persatu dan menanam benih padi satu-persatu lagi. Tentu hal ini masih tergolong cara tradisional, sehingga penulis ingin memberi alternatif untuk menggembangkan sistem pertanian yang lebih modern dan efektif yaitu dengan cara sistem hidroponik. Sistem hidroponik memiliki beragam jenis yang dapat diterapkan namun terdapat sistem sederhana yaitu sistem DFT (Deep Flow Technique) yang mana dapat diterapkan dan dilakukan dengan mudah oleh masyarakat.

Pandemi Covid-19 yang masih berlangsung membuat banyak orang kehilangan pekerjaannya dan ekonomi terhambat, tidak terkecuali bagi masyarakat Desa Jurangjero. Oleh sebab itu, penting untuk memutar otak agar tidak hanyut dalam situasi yang sama terus menerus. Memanfaatkan potensi hasil panen jagung yang melimpah dan dibuat menjadi produk lain seperti susu jagung dapat memberikan alternatif baru agar manusia bisa lebih produktif dan jika dijual memiliki nilai ekonomi yang lebih tinggi. Demikian juga sistem hidroponik bisa dilakukan untuk hobi baru di tengah pandemi serta bisa menghasilkan berbagai macam sayuran, buah-buahan yang bermanfaat bagi tubuh. Oleh karena itu, penulis akan membahas mengenai bagaimana pengelolaan potensi tanaman jagung dan peningkatan sistem pertanian menggunakan hidroponik.

\section{Metode Pengabdian}

Penelitian ini bertempat di Desa Jurangjero, Kecamatan Ngawen, Kabupaten Gunungkidul, Daerah Istimewa Yogyakarta, Indonesia. Desain penelitian yang akan digunakan adalah analisis deskriptif kualitatif. Analisis deskripsi kualitatif adalah sebuah metode analisis yang menempatkan penulis sebagai instrumen utama yaitu teknik penggabungan data serta analisis bersifat induktif [3]. Penelitian dilakukan dengan dukungan data primer terkait pengolahan jagung menjadi susu jagung dan hidroponik yang didapatkan melalui studi literatur melalui internet (website, jurnal, dan sebagainya). Data yang diambil dalam penelitian kualitatif ini dapat diolah dan dianalisis yang bersifat deskriptif yaitu dapat dilakukan dengan cara wawancara atau observasi [4].

Penelitian ini ingin mengetahui dan menggembangkan potensi desa yang dimiliki Desa Jurangjero karena begitu banyak hal yang bisa digunakan sebagai alternatif baru. Pada penelitian ini, pengabdian yang dilakukan kepada warga Desa Jurangjero berupa pemberdayaan petani jagung. Pemberdayaan masyarakat adalah upaya meningkatkan kemampuan dan potensi yang dimiliki masyarakat, sehingga masyarakat mampu mewujudkan jati diri untuk bertahan dan mengembangkan diri secara mandiri baik sosial maupun ekonomi [5]. Penelitian ini akan lebih banyak berfokus pada sumber-sumber literatur karena terdapat keterbatasan untuk terjun langsung dan mengamati observasi di lapangan.
Penelitian kualitatif deskripsi ini lebih cocok digunakan karena adanya pandemi covid-19.

Penelitian ini berfokus pada pengembangan pengolahan potensi tanaman jagung karena terdapat produksi melimpah di Desa Jurangjero sehingga ketika dijual ke pasar terkadang juga tidak habis. Oleh sebab itu, perlu adanya pemanfaatan produk olahan jagung dalam bentuk lain seperti susu jagung yang bisa bertahan lama serta memiliki banyak manfaat dan nilai ekonomis. Selain itu, penelitian ini juga akan berfokus kepada peningkatan produksi pertanian yaitu melalui sistem hidroponik. Sistem ini diharapkan dapat menjadi alternatif baru dalam dunia pertanian yang sudah banyak dilakukan dan memiliki manfaat yang besar juga.

\section{HASIL DAN PEMBAHAAN}

\section{Pengertian Hidroponik}

Hidroponik merupakan sebuah cara penanaman tanpa menggunakan media tanah namun dengan menggunakan larutan mineral yang kaya akan nutrisi atau dapat menggunakan bahan lainnya yang juga mengandung unsur hara yang diperlukan tanaman seperti sabut kelapa, serat mineral, pasir, pecahan batu bata, serbuk kayu, dan lain-lain untuk digunakan sebagai pengganti media tanah [6]. Hidroponik kini dianggap sebagai inovasi pertanian yang akan banyak digunakan di masa depan. Terdapat tiga konsep hidroponik yaitu:

a. Hidroponik murni. Artinya adalah proses hidroponik yang meliputi penggunaan sistem "pengikatan" dan memiliki fungsi untuk menjaga tanaman tetap berdiri, sehingga tanaman dapat mengembangkan akarnya ke dalam media air (nutrisi yang larut didalam air) tanpa perlu bantuan zat padat lainnya seperti tanah. Media hidroponik adalah media tanam tanpa tanah.

b. Hidroponik. Metode ini merupakan paling sering dijumpai dan banyak digunakan dalam teknik hidroponik karena menggunakan zat padat berpori seperti batu, kerikil dan material non-organic lainnya supaya nutrisi tanaman dapat tembus dan bersirkulasi dengan baik.

c. Hidroponik secara luas adalah metode gabungan dari dua teknik sebelumnya yaitu menggunakan substrats dan air tanpa media tanah namun jika membahas terkait teknik semi-hidroponik, istilah ini dapat diartikan pada penggunaan subtract non inert seperti serat kulit kelapa, beberapa kulit pohon, dan sekam padi [7].

\section{Manfaat Metode Hidroponik}

Hidroponik menjadi alternatif yang dapat digunakan untuk meningkatkan produktivitas tanaman terutama pada lahan sempit [8].Hidroponik memiliki banyak manfaat diantaranya adalah:

a. Penggunaan air menjadi lebih efisien. Tidak perlu untuk menyiram tanaman dengan air seperti yang dilakukan pada metode pertanian menggunakan media tanah. 
b. Tanaman dapat tumbuh menjadi lebih cepat. Hal ini karena nutrisi yang diserap berbentuk cairan dan tercukupi, serta tidak padat seperti tanah.

c. Dengan menggunakan metode bercocok tanam hidroponik, maka tidak memerlukan penggunaan lahan yang sangat luas karena dalam metode ini tanaman bisa disusun.

d. Tidak bergantung pada cuaca, sehingga bisa dilakukan kapan saja.

e. Hasil panen yang diperoleh menjadi lebih steril daripada hasil lahan perkebunan.

f. Resiko terserang penyakit dan hama menjadi lebih sedikit.

g. Menghemat penggunaan pupuk sehingga menjadi lebih efisien.

h. Menanam dengan cara hidroponik juga bisa menjadi selingan di waktu luang.

i. Sebagai media untuk meningkatkan kualitas SDM agar lebih optimal dalam pengelolaan dan pemanfaatan SDA. Serta mengajarkan kepedulian terhadap kelestarian lingkungan.

j. Sebagai wujud untuk menanggapi permasalahan menyempitnya lahan pertanian, produktivitas pertanian, dan pertumbuhan ekonomi masyarakat setempat.

k. Selain itu di masa pandemi saat ini tingkat produktivitas masyarakat menurun, sehingga penerapan metode hidroponik sangat bermanfaat untuk meningkatkan produktivitas masyarakat dengan budidaya tanaman.

\section{Media Hidroponik}

Ada 7 sistem yang dapat digunakan untuk media tanam hidroponik yaitu [9]

a. Aeroponic System yakni sistem yang menggunakan larutan nutrisi yang berasal dari penampungan kemudian disemprotkan melalui nosel (nozzle spray) yang berbentuk kabut dan langsung menuju akar sehingga akar akan lebih mudah menyerap larutan nutrisi dan oksigen. Memanfaatkan timer maka penyemprotan ke tanaman menggunakan nosel khusus dapat diatur dengan durasi yang diatur sehingga kebutuhan air tercukupi.

b. Sistem irigasi tetes (Drip irrigation). Sistem ini merupakan sistem hidroponik yang sering digunakan karena sederhana pemakaiannya. Tetap menggunakan timer untuk membantu kontrol kerja pompa air yang mana ketika pompa air tersebut dinyalakan pompa tersebut akan menetesmeneteskan nutrisi ke masing-masing tanaman secara perlahan. Modifikasi sistem irigasi tetes dengan memanfaatkan pipa berlubang tanpa komponen emitter (penetes) sehingga tanaman akan tetap tegak dan ditopang menggunakan media tanam lain seperti cocopeat, sekam bakar, batu zeolit, arang, macam-macam tanah.

c. NFT (Nutrient Film Technique) merupakan sistem yang cukup sering digunakan untuk para pebisnis karena sistem ini mengalirkan nutrisi yang terlarut di dalam air namun tidak menggunakan timer untuk pompanya dan berlangsung minimal 10 sampai 14 jam setiap harinya.
Nutrisi yang ada dialirkan ke dalam gully (wadah berbentuk persegi mirip dengan talang air) yang kemudian akan melewati akar tanaman dan kembali ke penampungan air. Air yang mengalir sekitar $2 \mathrm{~mm}$ sampai $4 \mathrm{~mm}$ dengan kemiringan gully sebesar $3 \mathrm{~cm}$ per $1 \mathrm{~m}$ nya. Tanaman dapat teraliri oleh air sepanjang hari sehingga menimbulkan riak dalam gully namun jika ada kerusakan pompa dapat menyebabkan tanaman mati dan memperlambat laju pertumbuhan tanaman.

d. DFT (Deep Flow Technique) mirip dengan NFT namun ketebalannya air nutrisi adalah 2 sampai $4 \mathrm{~cm}$ dan tidak ada kemiringan sehingga ketika sirkulasi terhenti tanaman dapat ternutrisi karena adanya genangan air tersebut. Di Indonesia karena untuk mendapatkan gully cukup susah maka diganti dengan pipa pvc yang berukuran 2 sampai 4 inchi.

e. Sistem EBB \& Flow yaitu sistem yang bekerja dengan adanya pembanjiran sementara di wadah pertumbuhan yang berisi nutrisi sampai air ada di batas yang diinginkan dan mengembalikan nutrisi tersebut ke dalam penampungan. Pompa yang digunakan disambungkan dengan timer dan mirip dengan sistem pasang surut karena akan ada waktu air tergenang dan membasahi akar dalam waktu yang ditentukan.

f. Water Culture yaitu sistem yang sederhana karena menggunakan styrofoam atau lainnya untuk menjadi penyangga tumbuhan dan mengapung langsung diatas cairan nutrisi dan menggunakan pompa udara (aerator) yang dialirkan dalam air stone dan membuat gelembung sebagai pemasok oksigen tambahan ke tanaman.

g. Sistem sumbu menjadi sistem yang paling sederhana dan dapat digunakan untuk pemula karena nutrisi hanya dialirkan ke dalam media pertumbuhan yang berada di dalam sebuah wadah dan menggunakan perantara seperti sumbu yang bisa dibuat dari kain flanel atau lainya.

\section{Definisi Produk Olahan Jagung}

Jagung merupakan tanaman yang cukup mudah untuk ditemui karena dapat menjadi komoditas yang dapat diandalkan, namun ketika saat panen petani jagung bisa mendapatkan limpahan jagung yang kemudian membuat harganya cukup rendah di pasaran [10].Jagung memang belum banyak menjadi olahan makanan terkadang hanya sebatas menggunakan untuk sayur atau jagung bakar oleh sebab itu Jagung dapat dibuat berbagai produk olahan jagung yang memanfaatkan jagung sebagai bahan utamanya agar dapat bertahan lama.

\section{Manfaat Produk olahan Jagung}

Produk olahan jagung memiliki banyak manfaat karena mengandung karbohidrat cukup tinggi, lemak, serat dan protein. Jagung yang diolah dengan baik menjadi produk olahan makanan atau minuman juga memiliki manfaat yang besar. Manfaat olahan jagung seperti susu jagung manis yang bermanfaat untuk memulihkan energi dalam 7 hari, menjaga kesehatan mata, usus, hati dan dapat digunakan sebagai obat diabetes karena kandungan manis dalam jagung adalah 
fruktosa bukan glukosa, menyegarkan tubuh, sebagai pengganti susu sapi [11]. Olahan jagung yang diolah tepat dapat juga membantu pencernaan, kaya protein sebagai antioksidan dan sebagainya.

Pada proses pembuatan olahan susu jagung, terdapat beberapa bahan utama yang digunakan yaitu:

1. Bahan-bahan yang digunakan

a. Beberapa buah jagung sesuai keinginan besaran olahan susu jagung

b. Beberapa liter air bersih

c. Gula pasir

d. Garam

2. Alat yang digunakan :
a. Blender
b. Pisau
c. Baskom
d. Sendok pengaduk
e. Kain saring
f. Panci
g. Kompor
h. Botol kemasan/ cup plastik.

\section{Cara pembuatan}

a. Blender jagung yang sudah dikupas dicuci bersih hingga halus, kemudian disaring dengan kain saring.

b. Saringan air jagung yang dihasilkan ditambahkan gula dan garam.

c. Kemudian panaskan kurang lebih selama 15 menit.

d. Selanjutnya kemas dalam botol kemasan atau cup plastik.

e. Simpan pada suhu yang dingin.

Susu Jagung diperoleh dengan cara diblender biji jagung yang sudah dipilih hingga halus. Hasil blender tersebut disaring untuk memisahkan sisa ampas biji jagung dan air jagung utuh. Selanjutnya air saringan jagung diberi rasa dengan menggunakan gula pasir dan juga garam sesuai banyaknya produksi dan sesuai selera. Hasil yang diperoleh masih berupa susu jagung mentah, kemudian susu dipanaskan kurang lebih selama 15 menit lalu di dinginkan sebentar selanjutnya siap untuk dikemas baik dalam kemasan botol atau pun cup plastik. Hal ini bertujuan untuk menjamin keamanan produk olahan susu jagung. Susu jagung mengandung serat lebih banyak sehingga baik untuk kesehatan. Kandungan karbohidrat yang terdapat dalam olahan susu jagung ini dipengaruhi oleh jumlah air yang ditambahkan, jangan waktu dan kondisi penyimpanan, serta kehalusan gilingan.
Berdasarkan paparan proses pembuatan olahan susu jagung, alat-alat dan juga bahan yang digunakan terbilang sangat sederhana dan mudah. Maka proses pembuatannya juga bisa untuk dipahami. Hal ini karena alat dan bahan yang digunakan hampir dimiliki semua rumah tangga dan juga tersedia di berbagai tempat penjualan. Sehingga memudahkan warga Desa Jurangjero untuk mengolah minuman susu jagung tersebut. Kelebihan olahan susu jagung ini karena bahan bakunya mudah didapat, terutama hasil dari perkebunan warga Desa Jurangjero itu sendiri.

Kemudian proses dalam penerapan metode hidroponik. Bentuk upaya penggembangan potensi desa yang dimiliki adalah mencoba metode baru dalam menanam dan membudidayakan tanaman sehingga nantinya dapat bernilai ekonomis yaitu dengan metode hidroponik DFT (Deep Flow Technique) karena bahan yang dibutuhkan cukup sederhana dan proses pembuatannya juga mudah. Adapun bahan-bahan yang diperlukan sebagai berikut:

a. Paralon (ukuran menyesuaikan seberapa besar kecil yang ingin dibuat. Biasanya berkisar 2-4 inchi)

b. Paralon 1 atau $1 / 2$ inchi untuk saluran fertigasi

c. Ploksok

d. Keni

e. Pompa air

f. Bak nutrisi

g. Lem PVC

h. Siku penyangga besi

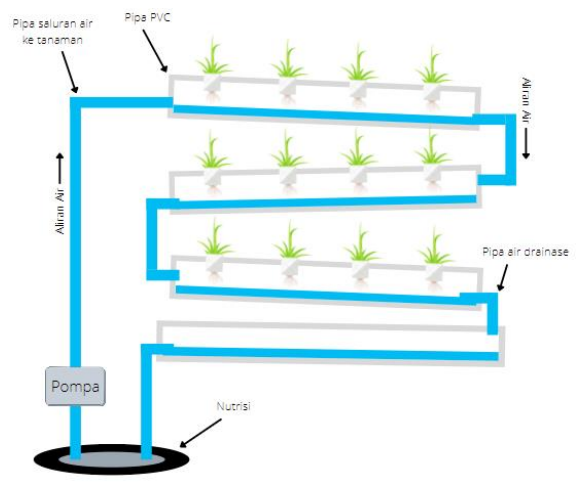

Gambar 1. Model Sistem Hidroponik DFT

Cara membuat hidroponik sistem DFT adalah sebagai berikut :

a. Persiapkan alat dan bahan yang akan digunakan untuk pembuatan hidroponik jenis DFT

b. Siapkan pipa paralon 1 dan $1 / 2$ inch lalu dipotong menjadi 6 ukuran yaitu $76,5 \mathrm{~cm} ; 55 \mathrm{~cm} ; 35 \mathrm{~cm} ; 33 \mathrm{~cm} ; 10 \mathrm{~cm}$; dan $8 \mathrm{~cm}$.

c. Setelah selesai memotong pipa-pipa tersebut selanjutnya akan dilubangi dan lubang tersebut berfungsi sebagai netpot. Besarnya lubang disesuaikan dengan ukuran 
netpot yang akan digunakan. Jarak antar lubang sekitar $20 \mathrm{~cm}$.

d. Setelah selesai melubangi pipa, langkah selanjutnya adalah melubangi penutup pipa agar air dapat mengalir ke dalam pipa tersebut.

e. Langkah selanjutnya menyusun kerangka utama, dengan menggunakan pipa sambungan dan sambungan $\mathrm{T}$ pipa serta knee kemudian disusun menjadi penyangga paralon tempat tanaman.

f. Membuat manifold hidroponik

g. Buat sambungan pipa menuju pompa

h. Setelah selesai membuat pipa sambungan menuju pompa, lakukan pengeboran terhadap tutup pipa dengan mata bor 4,5 mm, kemudian pasang nepel ulir pada lubang yang telah dibuat.

i. Kemudian pipa-pipa yang telah dibuat dirangkai menjadi seperti gambar diatas.

Metode ini memiliki keunggulan yaitu tidak membutuhkan instalasi listrik 24 jam hanya perlu memompa pada waktu tertentu saja apabila tidak sempat memompa tanaman tetap akan ternutrisi dari nutrisi yang tergenang di paralon namun memiliki kekurangan yaitu unsur hara mikro dan makro yang digunakan sebagai nutrisi tanaman yaitu oksigen terendam sehingga pasokan oksigen berkurang. Terlepas dari hal tersebut, teknik ini dapat diterapkan dan diandalkan sehingga bisa memunculkan nilai ekonomis dan memberikan peluang bagi siapapun untuk berbudidaya tanaman di rumah masing-masing.

\section{KESIMPULAN}

Setiap desa memiliki banyak potensi yang bisa dikembangkan. Contoh hal yang bisa dikembangkan adalah sistem tanam tonjo yang kemudian bisa dikembangkan menjadi sistem hidroponik. Masyarakat yang menggunakan sistem tersebut di masa pandemi sekarang bisa produktif dan sekaligus membantu alam karena hidroponik memiliki banyak manfaat yang semacam "penghijauan kecil" bagi bumi. Sistem hidroponik dapat digunakan untuk menanam sayursayuran seperti brokoli, sawi, cabai, tomat, selada, lobak, timun dan banyak lagi sehingga menghasilkan sayur yang lebih sehat tanpa pestisida. Sayuran tersebut dapat dijual kembali jika panen berlebih dengan harga yang mungkin bisa lebih murah dan dijangkau oleh banyak kalangan. Tidak hanya sayuran, apabila massyarakat mempunyai potensi dalam hasil jagung yang melimpah, perlu diketahui bahwa jagung memiliki banyak manfaat. Jagung bisa diolah menjadi susu jagung dan tentu bermanfaat bila dijual karena rasa yang unik dan sedap. Melalui dua cara ini, diharapkan masyarakat semakin tergerak hatinya untuk mengembangkan segala potensi yang dimiliki dari desa masing-masing dan membuat masyarakat lebih produktif di masa pandemi covid-19 yang mengharuskan banyak kegiatan di rumah saja.

\section{UCAPAN TERIMAKASIH}

Atas terlaksananya pengabdian dan penelitian yang bertempat di Desa Jurangjero, Ngawen, Gunung Kidul, peneliti mengucapkan terimakasih kepada LPPM Universitas Atma Jaya Yogyakarta yang sudah membantu dalam pelaksanaan terwujudnya makalah ini.

\section{DAFTAR PUSTAKA}

[1] a. f. suramal, nurkhaeni, r. b. sari, s. fatimah, and s. royanah, "Manfaat Pelatihan Budidaya Dengan Sistem Hidroponik Pada Masa Pandemi Covid-19 di kabupaten brebes," J. Univ. Negeri Semarang, 2005.

[2] Kementan, “Aneka Olahan Jagung,” Badan Penelit. dan Pengemb. Pertan., 2012.

[3] Sugiyono, Metode Penelitian Kuantitatif, Kualitatif dan R\&D. Bandung: Alfabeta, 2009.

[4] K. Poerwandari, "Pendekatan Kualitatif Untuk Penelitian Perilaku Manusia," Fak. Psikol. UI, 2005.

[5] K. Sellang, A. Yasin, and Yudi, "Pemberdayaan Masyarakat Melalui Wirausaha Budidaya Tanaman Jagung Di Desa Mattirotasi Kecamatan Watang Pulu Kabupaten Sidenreng Rappang," Pengabdi. pada Masy., no. June, 2017.

[6] S. A. Mulasari, "Penerapan Teknologi Tepat Guna (Penanam Hidroponik Menggunakan Media Tanam) Bagi Masyarakat Sosrowijayan Yogyakarta," J. Pemberdaya. Publ. Has. Pengabdi. Kpd. Masy., vol. 2, no. 3, p. 425, 2019, doi: 10.12928/jp.v2i3.418.

[7] Susilawati, Dasar - Dasar Bertanam Secara Hidroponik. Palembang: UPT. Penerbit dan Percetakan, 2019.

[8] A. P. Sudarmo, "Pemanfaatan pertanian secara hidroponik untuk mengatasi keterbatasan lahan pertanian di Daerah Perkotaan," Semin. Nas. Pengabdi. Kpd. Masyarakt Univ. Terbuka, pp. 1-8, 2018.

[9] B. H. Isnawan and Mulyono, "Beberapa Sistem Hidroponik \& Cara Budidaya Tanaman Dengan Hidroponik Sistem Sumbu* Beberapa Sistem Hidroponik," UMY Repos., no. September 2016, 2016, [Online]. Available: http://repository.umy.ac.id/bitstream/handle/123456 789/14300/Hidroponik\%0Asistem\%0Ainjeksi.pdf?s equence $=1$.

[10] M. Maherawati and S. Sarbino, "Diversifikasi Produk Olahan Jagung Manis Sebagai Upaya Peningkatan Nilai Tambah Bagi Petani Jagung di 
Daerah Wisata Pasir Panjang-Singkawang,” $J$. Pengabdi, vol. 1, no. 1, p. 17, 2018, doi: 10.26418/jplp2km.v1i1.25477.

[11] N. Hidayah, A. N. Istiani, and A. Septiani, "Pemanfaatan jagung (Zea mays) sebagai bahan dasar pembuatan keripik jagung untuk meningkatkan perekonomian masyarakat di desa panca tunggal," $J$. Pengabdi. Masy., vol. 1, no. 1, pp. 42-48, 2020, [Online]. Available: http://www.ejournal.radenintan.ac.id/index.php/ajp $\mathrm{m} /$ article/view/6181.

\section{PENULIS}

\begin{tabular}{|l|} 
Fransiska Olivia, Prodi Sosiologi, Fakultas \\
Ilmu Sosial dan Ilmu Politik, Universitas Atma \\
Jaya Yogyakarta.
\end{tabular}

Kevin, Prodi Teknik Informatika, Fakultas
Teknologi Industri, Universitas Atma Jaya
Yogyakarta.

